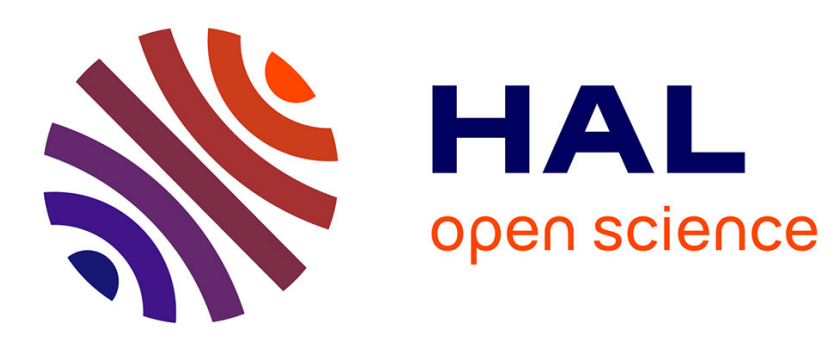

\title{
Impact of formulation on reconstitution and flowability of spray-dried milk powders
}

\author{
Tristan Fournaise, Jennifer Burgain, Carole Perroud, Joel Scher, Claire \\ Gaiani, Jérémy Petit
}

\section{- To cite this version:}

Tristan Fournaise, Jennifer Burgain, Carole Perroud, Joel Scher, Claire Gaiani, et al.. Impact of formulation on reconstitution and flowability of spray-dried milk powders. Powder Technology, 2020, 372, pp.107-116. 10.1016/j.powtec.2020.05.085 . hal-02881990

\section{HAL Id: hal-02881990 \\ https://hal.science/hal-02881990}

Submitted on 16 Apr 2021

HAL is a multi-disciplinary open access archive for the deposit and dissemination of scientific research documents, whether they are published or not. The documents may come from teaching and research institutions in France or abroad, or from public or private research centers.
L'archive ouverte pluridisciplinaire HAL, est destinée au dépôt et à la diffusion de documents scientifiques de niveau recherche, publiés ou non, émanant des établissements d'enseignement et de recherche français ou étrangers, des laboratoires publics ou privés. 
IMPACT OF FORMULATION ON RECONSITUTION AND FLOWABILITY

OF SPRAY-DRIED MILK POWDERS

3 Tristan FOURNAISE, Jennifer BURGAIN, Carole PERROUD, Joël SCHER, Claire GAIANI \& Jérémy PETIT*

\section{ABSTRACT}

10 The present study focuses on the impact of lipid content $(1.5,13.8$, and $26 \%(\mathrm{w} / \mathrm{w}))$ and air 11 incerperation in and pretreatment of dairy concentrates (air incorporation by whipping prior to 12 spray-drying) on the physicochemical and technofunctional characteristics of dairy powders. Spray13 drying was performed according to the following conditions: $200{ }^{\circ} \mathrm{C}$ inlet air temperature and $85^{\circ} \mathrm{C}$ 14 outlet air temperature. Physicochemical properties (particle size distribution, shape factors, moisture 15 content, water activity, and surface composition) of spray-dried powders were characterized in 16 order to explain their reconstitution properties and flowability.

17 The first part of the study revealed that changing the lipid content induced no significant difference

18 of powder reconstitution. It was evidenced that mean particle size of fatty powders was higher, thus

19 counteracting the negative effect of powder surface hydrophobicity on its reconstitution behavior.

20 Air incorporation in feed dairy concentrates did not significantly affect powder reconstitution 21 properties, even if surface lipid content and mean particle size were both decreased. Standard 22 wettability and dispersibility tests were not relevant to evaluate the reconstitution ability of 
23 investigated powders and all studied powders were classified as non-wettable and poorly 24 dispersible.

25 The second part of the study revealed that changing the lipid content induced a decrease in powder

26 flowability both in unconfined conditions and under high normal stress. Powders were cohesive due

27 to their low mean particle size and their surface lipid coverage, nevertheless feed concentrates

28 aeration induced an improvement of powder flowability by the decrease of in surface lipid content.

29 The bulk density (BD) and the compressed bulk density (CBD) both decreased with the lipid

30 content, and the aeration of feed concentrates did not impact the BD but led to a decrease in CBD.

31 Last, the compressibility increased with the lipid content and the aeration of feed concentrates, as

32 the latter induced the formation of smaller particles.

\section{KEYWORDS}

35 Dairy powder; formulation; spray-dryer; powder reconstitution; powder flowability 


\section{1. INTRODUCTION}

46 Spray-drying is a widely used process in the dairy powder industry, as it allows the production of

47 large amounts of powders with a good yield. Powder technofunctional properties are affected by the 48 physicochemical properties of powders, which are strongly dependent from the drying conditions 49 and formulation of feeding concentrates (dry extract, lipid and protein contents, whey protein/casein 50 ratio, pretreatments, drying conditions, etc.).

51 The pretreatment of feeding concentrates by whipping, leading to air incorporation, seems to have never been has recently begun to be studied in the milk powder field [1]. Air incorporation is mainly used for dairy matrices in the ice cream industry with the objective to monitor product texture: whipping is used to produce a foam stabilized by dairy proteins and retaining fat globules under the form of agglomerates at the surface of bubbles (i.e. at air/water interfaces); dairy proteins

56 also help to stabilize fat globule agglomerates $[2,3]$.

Surface composition of milk powders is markedly dependent from the composition of feeding concentrates. During the spray-drying of whole milk powder, lipids migrate to the surface of droplets by buoyancy (resulting from differences between water and lipid density), high

60 hydrophobicity, and slow diffusion in water, and thus resultsing in an overrepresentation of lipids at 61 particle surface. Milk proteins slowly diffuse slowly in water, but faster than lipids, resulting in a 62 lower protein content at particle surface. Lactose and minerals, due to their good water diffusion 63 ability and their hydrophilicity, are mainly found in the particle core. For low-fat powders such as 64 a skim milk powder, proteins are overrepresented at particle surface, because they are the teast 65 hydrophilic most surface active compounds of skim milk $[4,5]$.

66 Technofunctional properties of dairy powders such as reconstitution properties (wettability, 67 dispersibility, and solubility) and flowability are crucial for the agri-food industry and consumers. The phenomenon of powder reconstitution can be divided in four steps: wetting, sinking, dispersion, and solubilization. The wetting step designates the displacement of the solid/air interface 
70 by the solid/liquid interface when the powder comes into contact with the liquid. The sinking step 71 corresponds to the penetration of water in the immersed particle, causing its swelling. Powder dispersion states for the breakage of particle agglomerates into individual particles. The dissolution is the step where the granular structure disappears and the water-soluble components are solubilized [6-10]. Wettability is the ability of powders to immerse without stirring [7]. Powder wettability is sensitive to several powder physicochemical parameters, especially particle size: the smaller the particles, the longer their wetting time, then the poorer the powder wettability. Moreover, powder surface composition also affects the wetting time: an increase in the proportion of surface lipids is often deleterious for powder wettability [11-13]. Powder dispersibility corresponds to the dissociation of particle agglomerates into single particles. For dispersibility indices lower than 95

$80 \%$, the powder is considered as non-dispersible: for example, the dispersibility index of whole milk 81 powder (containing $26 \%$ lipids) is around $90 \%[6,7,13]$.

82 Solubility represents the ability of particles to dissolve into water and corresponds to the complete 83 loss of granular structure $[6,7,9]$. Like wettability, solubility decreases with surface lipid content or 84 mean particle size. Powder reconstitution depends on powder physicochemical properties: chemical 85 composition (protein, lipid, lactose, and minerals) and physical parameters such as particle size and 86 shape distributions $[11,12]$. Furthermore, the reconstitution behavior is affected by temperature, 87 stirring conditions, mineral content of the water solvent, etc. [14,15].

88 Powder flowability represents another big challenge for industrials: it is of utmost importance for

89 the control of the handling and transport of powders in pipes and hoppers. Powder flowability is 90 very dependent from powder physicochemical parameters: the flow is impaired by 91 particle cohesion, an increase of lipid content on particle surface (making particles sticky), a high 92 water content (increasing interparticular capillary interactions), a low mean particle size, a high 93 heterogeneity of particle sizes, and an elevated particle surface roughness [16,17]. Environmental 94 parameters also play a significant role: for instance, flowability is generally poorer at high 
95 temperature or high relative humidity (both favoring the glass transition phenomenon leading to the

96 apparition of a rubbery outer layer making the particle sticky), as well as with walls of high surface

97 roughness. Moreover, powder flow properties also depend from the type of stress applied to the

98 powder: flowability may differ in low (fluidization) and high stress conditions (rotational shear).

99 Various tests and flow parameters have been developed to evaluate and classify powder flowability, 100 particularly flow factor (ff) [18], cohesion, and basic flowability energy (BFE) [19].

101 The present study focuses on the impact of formulation (composition and pretreatments of feed 102 concentrates) on the reconstitution-ability and flowability of dairy powders. On one hand, dairy 103 powders differing in lipid content (issued from skim, semi-skim, and whole milks) were produced 104 by spray-drying at pilot-scale. On the other hand, the influence of concentrates pretreatment eed (air 105 incorporation by whipping) aeration prior to spray-drying was also investigated. The reconstitution 106 ability of spray-dried powders was evaluated through wettability, dispersibility, and solubility 107 indices which are classically employed by industrials.

\section{2. MATERIAL AND METHODS}

\subsection{Material}

110 Skim milk (SPRAY JA12 ALIM) and whole milk (SPRAY JG12 ALIM) powders used for the

111 preparation of milk concentrates were purchased from Lactalis Ingredients (Bourgbarré, France).

\section{2.2. Preparation of milk concentrates}

113 Concentrates were prepared by reconstituting skim and whole milk powders in distilled water at $11430 \%(\mathrm{w} / \mathrm{w})$ dry extract. Industrial powders were poured into distilled water at $20{ }^{\circ} \mathrm{C}$ under 115 mechanical stirring (ZR 2102 control, Heidolph, Germany) between 200 and 500 rpm with a 4116 bladed impeller $(2 \mathrm{~cm}$ length, $1 \mathrm{~cm}$ width) or a 3-hole square blade impeller $(7 \mathrm{~cm}$ length, $7 \mathrm{~cm}$ 117 width) to produce unaerated or aerated concentrates, respectively (Figure 1). The 3-hole square 118 blade impeller permitted to aerate feed concentrates by whipping until obtaining a foam. Once the 
119 powder was totally immersed, mixtures were stirred during $2 \mathrm{~h}$ at $20^{\circ} \mathrm{C}$, then overnight at $4{ }^{\circ} \mathrm{C}$

120 under slight agitation to ensure complete powder reconstitution.

121 Six concentrates varying in lipid content were produced: skim milk, semi-skim milk (using equal

122 amounts of skim and whole milk powders), and whole milk, each being aerated or not.

123 Six concentrates were produced: skim milk, semi-skim milk (using equal amounts of skim and

124 whole milk powders), and whole milk, each formulation being aerated or not. These concentrates

125 were then spray-dried in the same conditions in order to investigate the influence of formulation

126 (proximal composition, but also the way to prepare concentrates, i.e. with or without air 127 incorporation).

\subsection{Production of dairy powders by spray-drying}

129 Spray-drying was carried out on a Micra Spray MS 150 single effect spray-dryer (Anhydro, 130 Soeborg, Denmark), equipped with a bi-fluid nozzle (Fluid Cap $60100+$ Air Cap 120, Spraying 131 System, Wheaton, Illinois, USA). Spray-drying conditions were set at $200{ }^{\circ} \mathrm{C}$ drying air inlet 132 temperature and $85^{\circ} \mathrm{C}$ outlet temperature in view to obtain powders with good preservation abilities 133 (i.e., water activity ranging from 0.2 to 0.3 ) [20,21]. The concentrate was fed by a FASTLoad 134 peristaltic pump (VWR, Leuven, Belgium; $4.8 \mathrm{~mm}$ pipe internal diameter) and the feed concentrate 135 flow rate was regulated at $68.0 \mathrm{~mL} / \mathrm{min}$ to maintain the drying air outlet temperature at $85^{\circ} \mathrm{C}$ [22]. 136 Powders were placed in polypropylene bags just after sampling to limit degradations susceptible to 137 occur during storage (such as moisture uptake) and stored at $4{ }^{\circ} \mathrm{C}$.

138 To sum up, six powders were produced by spray-drying of the six concentrates prepared with 139 industrial milk powders (Table 1): unaerated skim milk powder (SMP), unaerated semi-skim milk 140 powder (SSMP), unaerated whole milk powder (WMP), aerated skim milk powder (ASMP), aerated 141 semi-skim milk powder (ASSMP), and aerated whole milk powder (AWMP). 


\subsection{Physicochemical characterization}

147 Particle size analysis was carried out with a laser granulometer (Mastersizer S, Malvern Instruments 148 Ltd, Malvern, UK) supplied with a $5 \mathrm{~mW}$ He-Ne laser operating at a wavelength of $632.8 \mathrm{~nm}$ with a $149300 \mathrm{RF}$ lens. Air dispersion was achieved with the Aero S module (Malvern). The dispersion 150 conditions were adapted to each powder: air pressure between 2 and 3 bar, feed rate between 60 and $15190 \%$, and hopper length between 2 and $3 \mathrm{~mm}$. Three replicates were analyzed for each sample. The 152 mean diameter in volume was chosen as size estimator. Classical granulometric parameters $\left(\mathrm{d}_{10}, \mathrm{~d}_{50}\right.$, 153 and $\mathrm{d}_{90}$ ) were calculated, where $\mathrm{d}_{\mathrm{x}}$ designates the diameter for which $x \%$ of the particles have a 154 smaller size. The width of the particle size distribution was evaluated with the span (Eq. (1)) [23].

$\operatorname{span}=\frac{d_{90}-d_{10}}{d_{50}}$

156 Scanning electron microscopy (SEM) was employed to observe the size, the morphology, and the

157 surface structure of milk powders. Powder samples were sputtered on double-sided carbon tape, 158 fixed to SEM stubs, and coated with carbon in a sputter coater (Polaron SC7640, Thermo VG 159 Scientific, East Grinstead, United Kingdom). The observations were performed at $\mathrm{x} 500$ 160 magnification under under vacuum using a scanning electron microscope (Hitachi S-4800, Japan) 161 operating at $1.0 \mathrm{kV}$ acceleration voltage [10]. 
163 The atomic surface contents in carbon, oxygen, and nitrogen of spray-dried powders were

164 determined from X-ray photoelectron spectroscopy (XPS) by using a Kratos AXIS Ultra (Kratos 165 Analytical, Manchester, UK) spectrometer with a monochromatic Al X-ray source at $150 \mathrm{~W}$.

166 Samples were outgassed under vacuum during $24 \mathrm{~h}$ before analysis. Each analysis was performed in 167 duplicate. XPS analysis provides atomic composition of powder surface up to $10 \mathrm{~nm}$ depth; 168 measurement area was about $700 \mu \mathrm{m} \times 300 \mu \mathrm{m}$ in analytical conditions of this study [21,24]. XPS 169 spectra were used to calculate the surface contents in proteins, lipids, and lactose by solving the 170 following equations (Eq. (2)) using the Excel solver (Windows, Microsoft, Redmond, USA). In 171 these equations, numerical values come from the experimental composition of pure milk proteins, 172 pure lactose, and anhydrous milk fat [21].

$$
\begin{aligned}
& C=0.685 \times P+0.608 \times L A+0.884 \times L I \\
& O=0.182 \times P+0.392 \times L A+0.113 \times L I \\
& N=0.133 \times P+0 \times L A+0.003 \times L I \\
& P+L A+L I=100 \%
\end{aligned}
$$

173 with:

$174-\mathrm{C}, \mathrm{O}$, and $\mathrm{N}(\%)$ : atomic concentrations of carbon, oxygen, and nitrogen at the powder surface, 175 respectively;

176 - P, LA, and LI (\%): surface content in proteins, lactose, and lipids, respectively. 
180 Water activity $\left(\mathrm{a}_{\mathrm{w}}\right)$ was measured with a HygroPalm23-AW portable $\mathrm{a}_{\mathrm{w}}$-meter (Rotronic, France) at

181 room temperature $\left(20^{\circ} \mathrm{C}\right)$ using a $3 \mathrm{~cm}$ powder layer $(15 \pm 1 \mathrm{~g})$ similarly to ISO 21807:2004 [25].

183 The water content was determined following ISO 5537:2004 [26] by the loss of water mass of 2.00

$184 \mathrm{~g} \pm 0.01 \mathrm{~g}$ powder after drying during at least $3 \mathrm{~h}$ at $103^{\circ} \mathrm{C}$ until a constant dry powder mass was 185 obtained.

\subsubsection{Reconstitution ability}

187 Reconstitution ability of spray-dried powders was evaluated through wettability, dispersibility, and 188 solubility indices determined by standard tests.

\subsubsection{Wettability}

190 Wettability was evaluated following IDF $87: 1979$ [13] as the time in seconds taken by $13.0 \pm 0.1 \mathrm{~g}$

191 of powder to become wet when gently deposited at the surface of $125.0 \mathrm{~g} \pm 0.1 \mathrm{~g}$ distilled water in a $192250 \mathrm{~mL}$ beaker.

\subsubsection{Dispersibility}

194 Dispersibility index was measured by a method adapted from IDF 87:1979 [13]. $13.0 \pm 0.1 \mathrm{~g}$ 195 powder was gently deposited on the surface of $125 \mathrm{~g}$ water at $20^{\circ} \mathrm{C}$ placed in a $400 \mathrm{~mL}$ beaker. The 196 mixture was manually stirred for $20 \mathrm{~s}$, then the mixture was allowed to rest for $30 \mathrm{~s}$. After that, the 197 mixture was passed through a $120 \mu \mathrm{m}$ sieve. The total dry matter of the liquid was determined by 198 drying at $103^{\circ} \mathrm{C}$ for $5 \mathrm{~h}$ (Eq. (3)).

200 Dispersibility $(\%)=\frac{W \times T}{100-(E+T)} \times \frac{100}{S}$

201 with: 
203 - T: dry matter content (\% w/w) of the liquid;

204 - E: dry matter content (\% w/w) of sampled powder;

205 - S: 13 g sampled powder (g).

206

$$
\text { 2.5.3.3 Solubility }
$$

207 Solubility was characterized as the proportion of powder able to be dissolved in distilled water 208 following a method adapted from ISO 8156:2005 [9]. It was determined by the addition of $2.5 \pm 0.1$ 209 g powder in $17.5 \mathrm{~mL}$ distilled water at $25^{\circ} \mathrm{C}$ in a $50 \mathrm{~mL}$ centrifugation tube followed by $30 \mathrm{~s}$ 210 stirring and centrifugation at $2294 \mathrm{x} g$ during $10 \mathrm{~min}$. Then, the supernatant was removed and the 211 pellet was added to $20 \mathrm{~mL}$ distilled water, followed by stirring and centrifugation at $2294 \mathrm{x} g$ 212 during $10 \mathrm{~min}$. The pellet was desiccated at $103{ }^{\circ} \mathrm{C}$ overnight to determine the mass of insoluble 213 residues, which allows determining the solubility index (Eq. (4)).

214 Solubility $(\%)=\frac{(S-M) \times 100}{S}$

215 with:

216 - M: undissolved sediment mass after desiccation (g);

217 - S: 2.5 g sampled powder (g).

\section{$218 \quad$ 2.6. Flow properties of milk powders}

219 Flow properties were analyzed using an FT4 powder rheometer with $25 \mathrm{~mm}$ accessories (Freeman 220 Technology, Worcestershire, UK).

$221 \quad$ 2.6.1. Stability test 
222 The stability test was carried out through a series of seven conditioning cycles and measurements of 223 the mixing energy of the powder bed placed in a $25 \mathrm{~mm}$ vessel [16,19]. Test cycles were performed 224 by rotating the blade $\left(-5^{\circ}\right.$ helix angle, $23.5 \mathrm{~mm}$ diameter, $100 \mathrm{~mm} / \mathrm{s}$ tip speed $)$ into and through the 225 sample of powder bed placed in a measurement cell $(25 \mathrm{~mm}$ x $25 \mathrm{~mL})$. Stability test cycles were 226 realized by the rotating movement of the blade into and through a powder bed contained in the 227 measurement cell $(50 \mathrm{~mm} \times 260 \mathrm{~mL}$ glass cylinder $)$ at a tip speed of $-100 \mathrm{~mm} / \mathrm{s}$ and helix angle of $228-5^{\circ}$

229 The basic flowability energy (BFE) is the energy needed in the seventh test to displace a 230 conditioned powder sample during downwards moving of the blade, it mainly depends on 231 compressibility, consolidation level, and density of the powder bed [16]. Easy-flowing behavior 232 corresponds to a low BFE; on the contrary, a high BFE is generally obtained for poorly-flowing 233 powders.

234 The specific energy (SE) (Eq. (6)) is the energy needed to displace the conditioned powder bed 235 during upwards testing divided by the mass of analyzed powder sample. It depends on powder 236 cohesion, particle size, shape, surface roughness and composition, as well as chemical and physical 237 interactions between particles [16].

$$
S E=\frac{\frac{(\text { Up energy cycle } 6+\text { Up energy cycle } 7)}{2}}{\text { Powder mass }}(\mathrm{mJ} / \mathrm{g})
$$

238 Powder flow behavior can be classified on the basis of the SE value as follows:
- $\quad \mathrm{SE}<5 \mathrm{~mJ} / \mathrm{g}:$ low cohesion
$240 \quad-5 \mathrm{~mJ} / \mathrm{g}<\mathrm{SE}<10 \mathrm{~mJ} / \mathrm{g}$ : moderate cohesion
$241 \quad-\mathrm{SE}>10 \mathrm{~mJ} / \mathrm{g}$ : high cohesion

242 The classification provided by Freeman Technology is specifically adapted for the FT4 powder 243 rheometer. 
245 Compressibility test allows to measure the evolution of the powder density as a function of the 246 applied normal stress $[16,27,28]$. The test proceeds by begins with three conditioning cycles in 25 $247 \mathrm{~mm}$ vessel with a $23.5 \mathrm{~mm}$ blade, then the vessel was split in a measurement cell $(25 \mathrm{~mm} \times 10 \mathrm{~mL})$. 248 The blade was replaced by a $23.5 \mathrm{~mm}$ vented piston after the powder was subjected to nine levels of 249 normal stress from 0.5 to $15 \mathrm{kPa}$. The powder compressibility depends on the particle size and 250 shape, surface roughness and composition, powder bed porosity, and interparticular cohesion. The 251 compressibility allows to obtaining information on the powder density before and after compression 252 at $15 \mathrm{kPa}$, respectively named the bulk density (BD) (Eq. (7)) and the compressed bulk density 253 (CBD) (Eq. (8)) here.

Bulk density $=\frac{\text { Powder mass }}{\text { Volume of the measurement cell }}(\mathrm{g} / \mathrm{mL})$

$$
\text { Compressed Bulk Density }=\frac{\text { Powder mass }}{\text { Volume of the powder bed after compression }}(\mathrm{g} / \mathrm{mL})
$$

256 The shear cell test is intended to evaluate flowability under a high shear rate; it also allows 257 determining powder cohesion. The test started with a conditioning cycle to homogenize the powder 258 with the $23.5 \mathrm{~mm}$ blade in the $25 \mathrm{~mm}$ container. Then the powder was compacted under a normal 259 stress of $9 \mathrm{kPa}$ with a ventilated piston of $23.5 \mathrm{~mm}$. The excess powder was elucidated removed to 260 obtain a measuring cell of $25 \mathrm{~mm} \times 10 \mathrm{~mL}$, and then help the shear of the powder bed to be was 261 subjected to a shear stress of 7 to $3 \mathrm{kPa}$ by $1 \mathrm{kPa}$ steps $[16,19,28,29]$.

262 The shear test allowed to obtain different powder properties such as cohesion ( $\mathrm{kPa})_{-}$, and the 263 flowability index or flow factor (ff) (Eq. (9)). 


$$
f f=\frac{\sigma_{1}}{\sigma_{c}}
$$

264 With:

- $\quad \sigma_{1}$ : unconfined yield strength $(\mathrm{Pa})$

$266-\sigma_{c}:$ major principle stress $(\mathrm{Pa})$

267 Powder flowability can be deduced from flow factor values by using Jenike's classification [18]:

- $\quad f f<1$ : not flowing

$269 \quad-\quad 1<f f<2$ : very cohesive

$270 \quad-\quad 2<f f<4:$ cohesive

$271 \quad-\quad 4<f f<10$ : easy flowing

$272 \quad-10<f f:$ free flowing

\subsection{Statistical analysis}

274 All analyses were triplicated to ensure a good analytical repeatability and presented values 275 correspond to means \pm standard deviations. Data were statistically analyzed by one-way ANOVA 276 performed with Excel version 2016 and means were separated by Tukey's HSD test at $\mathrm{p}<0.05$ 277 significance level.

\section{RESULTS AND DISCUSSION}

\subsection{Particle size distribution}

281 The size of spray-dried particles ranged from 1 to $200 \mu \mathrm{m}$, in agreement with the low particle sizes 282 generally obtained with the pilot spray-dryer used in this study [22,30-32]. Their $\mathrm{d}_{50}$ was comprised 283 between 11.6 and $36.7 \mu \mathrm{m}$ (Figures $2 \&$ Tables 2). All particle size distributions were monomodal 284 and particle sizes were rather moderately dispersed around the mean particle size (as reflected by 
285 the moderate span values ranging from 2.0 to 3), except for the SMP was composed of particles of 286 heterogeneous sizes as reflected by its higher span (Table 2 \& Figure 2). Feed concentrate aeration 287 prior to spray-drying led to a decrease in particle size and a narrowing of the particle size 288 distribution. This may be explained by the effect of air incorporation (as dissolved air or under the 289 form of bubbles) in the concentrate: in fact, it was expected to decrease the density and/or the 290 viscesity of the concentrate, both thus facilitating the breakup of the liquid jet during the spraying 291 operation [32-35]. Therefore, aerated concentrates resulted in smaller droplets in the spray and 292 smaller particles at the outlet of the spray-dryer. Particle size-The mean particle size $\mathrm{d}_{50}$ decreased 293 with lipid content for SMP, SSMP and WMP powders, but this impact of lipid content was not 294 evidenced for ASMP, ASSMP and AWMP powders. The decrease in particle size for powders 295 coming from unaerated feed concentrates was probably due to the decrease in viscesity and/or 296 density of feed concentrates when the lipid content was increased. This effect of lipid content on 297 particle size was negligible when spray-drying aerated concentrates, probably because the impact of 298 concentrates aeration on its viscesity and density is well higher than the influence of lipid content.

\section{Figure 2}

300 Table 2

\subsection{Particle appearance}

302 According to SEM images, spray-dried milk powders (SSMP, ASSMP, WMP, and AWMP) had a 303 smoother appearance than skim milk powders (SMP and ASMP) particles (Figure 3) [5]. This is 304 likely to come from the presence of a lipid layer at the particle surface, formed by lipid migration 305 by buoyancy in the sprayed droplet [36]. In addition, granulometric results were confirmed by 306 microscopic observations: a rather large heterogeneity of particle sizes was observed for SMP. 307 Also, the decrease in particle size induced by the aeration of feed concentrates prior to spray-drying 308 was confirmed by SEM images. 
Figure 3

\subsection{Surface composition}

311 XPS analyses (Figure 4) permitted to highlight the influence of lipid content on surface composition

312 of milk particles. For WMP and SSMP powders, lipids were overrepresented and lactose was

313 underrepresented, as often observed for milk powders [5]. This phenomenon is well known for

314 powders containing lipids (even in low proportions); in the current study for example, the SSMP

315 powder had $55 \%$ surface lipids for an overall lipid content of $13.8 \%(\mathrm{w} / \mathrm{w})$.

316 A marked decrease (over half of surface lipids) in surface lipid content was observed for powders

317 produced from aerated feed concentrates. Indeed, it is well known that during drying, lipids migrate 318 owing to buoyancy to the air/water interfaces, especially at the droplet surface. It can be

319 hypothesized that droplets coming from aerated feed concentrates may have a higher proportion of 320 occluded air, thus embedding more air/water interfaces. After migration due to buoyancy and

321 hydrophobicity, lipids can be found either at the embedded air/water interfaces or at the droplet 322 surface [1-3]. Therefore, the lipid content at the surface of powders produced from aerated feed 323 concentrates was expected to be lower than for powders coming from unaerated feed concentrates, 324 as if lipids were encapsulated [37].

325 Figure 4

\subsection{Powder interactions with water}

327 Spray-dried powders had a low water activity between 0.15 and 0.29 (Table 3), which is favorable 328 to their good preservation; indeed, the ideal water activity for the preservation of food products, 329 especially dairy, ranges from 0.20 to 0.35 [7]. Thus, during storage, produced powders will be 330 almost insensitive to alteration reactions, except for lipid oxidation of powders containing a 331 significant proportion of lipids such as WMP, because its water activity was slightly below 0.2 [38]. 
332 The water content of all spray-dried powders respected the maximum water content recommended 333 for dairy powders (5 g/100 g on wet basis) [39]. Despite rigorously identical spray-drying 334 conditions, the water content slightly varied, because powder composition changed and their 335 different components vary in hygroscopicity.

336 The wettability of commercial milk powders generally ranges between $24 \mathrm{~s}$ for skim milk powders 337 and $120 \mathrm{~s}$ for whole milk powders. The dispersibility of commercial milk powders also varies 338 between $90 \%$ for WMP and $95 \%$ for SMP [7]. Poor wettability of studied powders was expected 339 due to the fineness of powders produced by the pilot-scale spray-dryer owing to nozzle geometry 340 (mean particle size $\mathrm{d}_{50}$ under $90 \mu \mathrm{m}$ ); in fact, wetting times greater than 90 min were obtained for 341 investigated powders. For the same reason, poor dispersibility was also expected; in this study, 342 spray-dried powders had very low dispersibility below $25 \%[14,40]$. Then, this tremendous 343 influence of particle size did not make it possible to highlight the impact of the lipid content on 344 powder wettability and dispersibility. Powder wettability was very poor reflected by a wettability 345 time over 90 min and dispersibility was also very poor under $25 \%$, which results in all likelihood 346 from the fineness of spray-dried particles.The dispersibility results were inconclusive because all 347 the powders were non-dispersible $[14,40]$.

348 Solubility of SMP, ASMP, SSMP, ASSMP, WMP, and AWMP did not significantly differ (Table 349 3). Thus, lipid content and concentrate aeration prior to spray-drying did not affect powder 350 solubility, contrary to what was expected for powders varying in lipid content $[7,41]$. These results 351 evidenced that the low mean particle size had a well more significant effect than milk powder 352 compesition on its solubility than milk powder composition $[7,42,43]$.

353 Table 3 
356 BFE of spray-dried powders significantly increased with the increase in lipid content both for 357 powders coming from aerated and unaerated feed concentrates (Table 4). This indicates that powder 358 flowability was impaired by the presence of surface lipids, consistently with the findings of 359 Shrestha et al. [44] and Kim [45]. Indeed, fat surface coverage is expected to make particles 360 stickier, thus increasing powder cohesion.

361 Moreover, aeration of feed concentrates induced a decrease in particle size, thus impairing powder

362 flowability, as illustrated by the higher BFE of ASMP, ASSMP, and AWMP [17,20].

363 Regarding SE values, three powder groups can be formed: powders of SE close to $5 \mathrm{~mJ} / \mathrm{g}$ 364 corresponding to rather low cohesion (SMP), powders with a SE around $7-8 \mathrm{~mJ} / \mathrm{g}$, moderately 365 cohesive (SSMP, WMP, ASMP), and cohesive powders with SE close or above $10 \mathrm{~mJ} / \mathrm{g}$ (ASSMP, 366 AWMP). It is obvious that a higher lipid content made powders more cohesive, owing to the 367 increase in surface stickiness, whereas aeration of feed concentrates was deleterious for powder 368 flowability owing to the decrease in particle size. Indeed, electrostatic interactions and friction are 369 expected to be promoted between smaller particles, owing to the larger contact area between 370 particles $[45,46]$.

371 Overall, the modification of fat content seemed to impair powder flowability in an unconfined 372 environment. as much as aeration of feed concentrates

373 Table 4

376 The compressibility test allowed to obtaining information on conditioned bulk density (CBD), bulk 377 density (BD), and powder compressibility at $15 \mathrm{kPa}$ (Figure. 5, Table 4).

378 Aeration of feed concentrates did not induce any significant CBD, BD, or compressibility change, 
380 was slightly increased when the feed concentrate was aerated. This may be explained by the fact

381 that mean particle size and span of powders coming from aerated concentrates were both smaller

382 and have opposite effects on powder compressibility. Indeed, smaller particles are generally more

383 cohesive and thus more compressible, whereas smaller span indicates a better homogeneity of

384 particle sizes, which makes powders less compressible [47,48]. Hence, it may be concluded from

385 these results that aeration of concentrates did not have a great effect on powder cohesion: a small

386 increase in powder compressibility was sometimes denoted, which may be indicative of a small

387 increase in powder cohesion. This is indicative of higher cohesion of powders coming from aerated

388 feed concentrates and meets observations formulated from stability test results.

389 Besides, powders containing fat (SSMP, WMP, ASSP, and AWMP) had a reduced lower CBD than

390 skim milk powders, as the presence of surface fat is known to increased powder cohesion. Thus,

391 their sensitivity to compression of fat-containing powders was higher, leading to higher BD and

392 compressibility. This may be a sign of higher cohesion of fat-containing powders, which was

393 obviously expected owing to the stickiness of fat material. Then, fat-containing powders appeared

394 to become cohesive when surface fat content exceeded circa $10 \%$ (intermediate value between

395 surface fat contents of SMP and ASSMP).

The smaller particles size obtained by feed concentrate aeration can explain the higher

398 compressibility of ASSMP and AWMP in comparison with SSMP and WMP, respectively-[49]:

399 The higher compressibility of SMP in comparison with ASMP could be explained by its the higher

400 span-indicating a probable large proportion of large particles, less sensitive to compression (Table

$40132)[47,48]$.

402 Overall, the lipid content seemed to affect powder compressibility more than aeration of feed 403 eoncentrates. 


\section{Figure 5}

405 3.5.3. Shear cell test

406 Results of the shear cell test are displayed in Figure 6 and Table 5. On one hand, powders 407 containing significant proportions of lipids (SSMP, WMP, ASSMP, AWMP) were highly cohesive, 408 owing to their previously evoked surface stickiness, in agreement with stability and compressibility 409 results. The flow factor of these powders was found near 2, indicating the difficulty to make these 410 cohesive powders flow. Powders almost free from lipids (SMP and ASMP) were rather easy411 flowing powders, having a low cohesion. This confirms that the presence of surface fat has a 412 significant influence on powder flowability.

413 On the other hand, aeration of feed concentrates seemed not to have a tremendous effect on powder 414 flow in high shear stress conditions, but it induced a slight improvement (respectively, impairment) 415 of skim milk powder (respectively, semi-skim, and whole milk powders) flowability, as denoted by 416 the small decrease (respectively, increase) in powder cohesion and the small increase (respectively, 417 decrease) in flow factor. These results slightly differ from those of the stability test, which showed 418 that the negative impact of the smaller particle size of ASMP powder on its flowability exceeded 419 the positive impact its lower surface fat content [46].

420 Overall, the modification of fat content seemed to impair powder flowability in high normal stress

421 conditions more than aeration of feed concentrates. The higher impact of lipid content in high stress 422 conditions than in unconfined ones could be a consequence of the release of free fat at powder 423 surface under high normal stress.

424 Figure 6

\section{4. CONCLUSION}

426 In the present study, the link between formulation (composition and pretreatment) of the feed 427 concentrate used for spray-drying, powder physicochemical properties, and reconstitution ability 
428 were explored. First, the single effect pilot-scale dryer led to the production of small spray-dried 429 particles, owing to nozzle geometry. It was evidenced that the feed concentrate aeration prior to 430 spray-drying resulted in a great decrease in particle size. For the first time, the use of this processing 431 step (aeration of feed concentrates) was evidenced to impact particle surface composition (lipid 432 surface content was decreased) along with particle size distribution. As powder functional 433 properties (reconstitution ability, stability during storage, flowability) are related to powder 434 physicochemical properties, particle size and lipid location are of great importance and must be 435 managed by industrials.

436 Concentrate aeration prior to spray-drying has been evidenced to allow reducing the surface fat 437 content. Thus, industrial may interestingly reduce interparticular cohesion and thus increase powder 438 flowability by aerating concentrates prior to spray-drying. The decreased surface fat content may 439 also be beneficial for improving powder reconstitution ability and decrease powder sensitivity to 440 caking. In order to avoid lipid oxidation, nitrogen could be incorporated instead of air.

442 The lipid content was not clearly linked to powder reconstitution behavior as its influence was 443 overwhelmed by the impact of the small particle size of investigated powders. The small particle 444 size of powders obtained by spray-drying at pilot scale induced the formation of non-wettable and 445 non-dispersible powders. It would be interesting to work on the geometry of the bi-fluid nozzle used 446 for spray-drying with the objective to produce larger particles of size comparable to commercially 447 available powders.

449 The modification of lipid content seemed to impair powder flowability in an unconfined 450 environment as much as aeration of feed concentrates. A higher lipid content seemed to increase 451 powder compressibility more than aeration of feed concentrates. Skim milk powders were rather 452 easy-flowing and had a low cohesion, whereas all other powders, containing a significant 453 proportion of lipids, were cohesive, thus having a poor flowability. Overall, the modification of fat 
content seemed to impair powder flowability in high stress conditions and more than aeration of

455 feed concentrates. This greater influence of lipid content in high normal stress conditions may result 456 from release of free fat at particle surface under compression.

\section{ACKNOWLEDGEMENTS}

459 The authors acknowledge support of the LIBio by the "Impact Biomolecules" project of the 460 "Lorraine Université d'Excellence" (Investissements d'avenir - ANR). Moreover, the authors 461 acknowledge the help given by the LIBio scientific team for the training and provision of analytical 462 devices.

463 We thank Aurélien RENARD of the spectroscopy and microscopy Core Facility of SMI LCPME 464 (Université de Lorraine - CNRS - http://www.lcpme.cnr-nancy.fr) should also be thanked for 465 performing XPS analyses.

\section{REFERENCES}

[1] L. Kosasih, B. Bhandari, S. Prakash, N. Bansal, C. Gaiani, Effect of whole milk concentrate carbonation on functional, physicochemical and structural properties of the resultant spray dried powder during storage, Journal of Food Engineering. 179 (2016) 68-77. https://doi.org/10.1016/j.jfoodeng.2016.02.005.

[2] G.A. van Aken, Aeration of emulsions by whipping, Colloids and Surfaces A: Physicochemical and Engineering Aspects. 190 (2001) 333-354. https://doi.org/10.1016/S0927-7757(01)00709-9.

[3] L. Kosasih, B. Bhandari, S. Prakash, N. Bansal, C. Gaiani, Physical and functional properties of whole milk powders prepared from concentrate partially acidified with $\mathrm{CO} 2$ at two temperatures, International Dairy Journal. 56 (2016) 4-12. https://doi.org/10.1016/j.idairyj.2015.12.009.

[4] E.H.-J. Kim, X.D. Chen, D. Pearce, On the Mechanisms of Surface Formation and the Surface Compositions of Industrial Milk Powders, Drying Technology. 21 (2003) 265-278. https://doi.org/10.1081/DRT-120017747.

[5] I. Murrieta-Pazos, C. Gaiani, L. Galet, J. Scher, Composition gradient from surface to core in dairy powders: Agglomeration effect, HAL CCSD, 2012.

[6] J.A. O'Mahony, P.L.H. McSweeney, Advanced dairy chemistry. Volume 1B: Proteins: Applied aspects. Fourth Edition, Springer, 2016. http://125.234.102.149:8080/dspace/handle/DNULIB_52011/7900 (accessed January 17, 2018).

[7] P. Schuck, R. Jeantet, A. Dolivet, Analytical Methods for Food and Dairy Powders, John Wiley \& Sons, 2012.

[8] A. Mimouni, H.C. Deeth, A.K. Whittaker, M.J. Gidley, B.R. Bhandari, Investigation of the microstructure of milk protein concentrate powders during rehydration: Alterations during storage, Journal of Dairy Science. 93 (2010) 463-472. https://doi.org/10.3168/jds.2009-2369. 
[9] AFNOR, Dried milk and dried milk products - Determination of insolubility index, ISO 8156:2005. (2005).

[10]C. Gaiani, Étude des mécanismes de réhydratation des poudres laitières [Ressource électronique]: influence de la structure et de la composition des poudres, Mémoire de thèse de doctorat soutenu le 5 juillet 206, Vandoeuvre-les-Nancy: INPL. 2006., 2006.

[11]A. Sharma, A.H. Jana, R.S. Chavan, Functionality of Milk Powders and Milk-Based Powders for End Use Applications-A Review, Comprehensive Reviews in Food Science and Food Safety. 11 (n.d.) 518-528. https://doi.org/10.1111/j.1541-4337.2012.00199.x.

[12]E.H.-J. Kim, X.D. Chen, D. Pearce, Surface characterization of four industrial spray-dried dairy powders in relation to chemical composition, structure and wetting property, Colloids and Surfaces B: Biointerfaces. 26 (2002) 197-212. https://doi.org/10.1016/S0927-7765(01)00334-4.

[13]IDF, Détermination de la dispersibilité et de la mouillabilité, International Dairy Federation, Brussels, Belgium. (1987).

[14]B. Freudig, S. Hogekamp, H. Schubert, Dispersion of powders in liquids in a stirred vessel, Chemical Engineering and Processing: Process Intensification. 38 (1999) 525-532. https://doi.org/10.1016/S02552701(99)00049-5.

[15]W.R. Mitchell, L. Forny, T.O. Althaus, G. Niederreiter, S. Palzer, M.J. Hounslow, A.D. Salman, Mapping the rate-limiting regimes of food powder reconstitution in a standard mixing vessel, Powder Technology. 270 (2015) 520-527. https://doi.org/10.1016/j.powtec.2014.08.014.

[16]H. Mitra, H.A. Pushpadass, M.E.E. Franklin, R.P.K. Ambrose, C. Ghoroi, S.N. Battula, Influence of moisture content on the flow properties of basundi mix, Powder Technology. 312 (2017) 133-143. https://doi.org/10.1016/j.powtec.2017.02.039.

[17]E.H.-J. Kim, X.D. Chen, D. Pearce, Effect of surface composition on the flowability of industrial spraydried dairy powders, Colloids and Surfaces B: Biointerfaces. 46 (2005) 182-187. https://doi.org/10.1016/j.colsurfb.2005.11.005.

[18]A.W. Jenike, Gravity Flow of Bulk Solids, Bulletin 108, Engineering Experiment Station, University of Utah. (1961).

[19]R. Freeman, Measuring the flow properties of consolidated, conditioned and aerated powders - A comparative study using a powder rheometer and a rotational shear cell, Powder Technology. 174 (2007) 25-33. https://doi.org/10.1016/j.powtec.2006.10.016.

[20]P. Schuck, A. Dolivet, R. Jeantet, Les poudres laitières et alimentaires [Texte imprimé] : techniques d'analyse, Paris : Éd. Tec \& Doc-Lavoisier. impr. 2012, cop. 2012., 2012.

[21] Y. Nikolova, J. Petit, A. Gianfrancesco, C.F.W. Sanders, J. Scher, C. Gaiani, Impact of Spray-Drying Process Parameters on Dairy Powder Surface Composition and Properties, Drying Technology. 33 (2015) 1654-1661. https://doi.org/10.1080/07373937.2015.1060494.

[22] J. Guerin, J. Petit, J. Burgain, F. Borges, B. Bhandari, C. Perroud, S. Desobry, J. Scher, C. Gaiani, Lactobacillus rhamnosus GG encapsulation by spray-drying: Milk proteins clotting control to produce innovative matrices, Journal of Food Engineering. 193 (2017) 10-19. https://doi.org/10.1016/j.jfoodeng.2016.08.008.

[23]C. Salameh, J. Scher, J. Petit, C. Gaiani, C. Hosri, S. Banon, Physico-chemical and rheological properties of Lebanese kishk powder, a dried fermented milk-cereal mixture, Powder Technology. 292 (2016) 307-313. https://doi.org/10.1016/j.powtec.2016.01.040.

[24]M.A. Nawaz, C. Gaiani, S. Fukai, B. Bhandari, X-ray photoelectron spectroscopic analysis of rice kernels and flours: Measurement of surface chemical composition, Food Chemistry. 212 (2016) 349 357. https://doi.org/10.1016/j.foodchem.2016.05.188.

[25]AFNOR, Microbiology of food and animal feeding stuffs - Determination of water activity, ISO 21807:2004. (2004).

[26]AFNOR, Dried milk - Determination of moisture content (Reference method), ISO 5537:2004. (2004).

[27]J.V.C. Silva, J.A. O'Mahony, Flowability and wetting behaviour of milk protein ingredients as influenced by powder composition, particle size and microstructure, International Journal of Dairy Technology. 70 (2017) 277-286. https://doi.org/10.1111/1471-0307.12368.

[28]A. Vasilenko, B.J. Glasser, F.J. Muzzio, Shear and flow behavior of pharmaceutical blends - Method comparison study, Powder Technology. 208 (2011) 628-636.

https://doi.org/10.1016/j.powtec.2010.12.031. 
[29]R.E. Freeman, J.R. Cooke, L.C.R. Schneider, Measuring shear properties and normal stresses generated within a rotational shear cell for consolidated and non-consolidated powders, Powder Technology. 190 (2009) 65-69. https://doi.org/10.1016/j.powtec.2008.04.084.

[30]A. N. Khanji, F. Michaux, J. Petit, D. Salameh, T. Rizk, J. Jasniewski, S. Banon, Structure, gelation, and antioxidant properties of curcumin-doped casein micelle powder produced by spray-drying, Food \& Function. 9 (2018) 971-981. https://doi.org/10.1039/C7FO01923H.

[31] Y. Nikolova, J. Petit, C. Sanders, A. Gianfrancesco, N. Desbenoit, G. Frache, G. Francius, J. Scher, C. Gaiani, Is it possible to modulate the structure of skim milk particle through drying process and parameters?, Journal of Food Engineering. 142 (2014) 179-189. https://doi.org/10.1016/j.jfoodeng.2014.05.026.

[32] S. Mandato, E. Rondet, G. Delaplace, A. Barkouti, L. Galet, P. Accart, T. Ruiz, B. Cuq, Liquids' atomization with two different nozzles: Modeling of the effects of some processing and formulation conditions by dimensional analysis, Powder Technology. 224 (2012) 323-330. https://doi.org/10.1016/j.powtec.2012.03.014.

[33]S.V. Crowley, I. Gazi, A.L. Kelly, T. Huppertz, J.A. O'Mahony, Influence of protein concentration on the physical characteristics and flow properties of milk protein concentrate powders, Journal of Food Engineering. 135 (2014) 31-38. https://doi.org/10.1016/j.jfoodeng.2014.03.005.

[34]J. Petit, S. Méjean, P. Accart, L. Galet, P. Schuck, C. Le Floch-Fouéré, G. Delaplace, R. Jeantet, A dimensional analysis approach for modelling the size of droplets formed by bi-fluid atomisation, Journal of Food Engineering. 149 (2015) 237-247. https://doi.org/10.1016/j.jfoodeng.2014.10.022.

[35]J. PIEN, M. G. MAURICE, RELATIONS DE DENSITÉ DANS LES PRODUITS LAITIERS, Le Lait. 18 (1938) 582-610.

[36]M.L. Vignolles, C. Lopez, J.J. Ehrhardt, J. Lambert, S. Mejean, R. Jeantet, P. Schuck, Methods' combination to investigate the suprastructure, composition and properties of fat in fat-filled dairy powders, JOURNAL OF FOOD ENGINEERING. (2009) 154.

[37]P. Faldt, B. Bergenstahl, G. Carlsson, The Surface Coverage of Fat on Food Powders Analyzed by Esca (Electron Spectroscopy for Chemical Analysis), Food Structure. 12 (1993). https://digitalcommons.usu.edu/foodmicrostructure/vol12/iss2/10.

[38] Y.H. Roos, Importance of glass transition and water activity to spray drying and stability of dairy powders, Lait. 82 (2002) 475-484. https://doi.org/10.1051/lait:2002025.

[39]FAO (Food and agriculture organization of the united nations), CODEX STANDARD FOR MILK POWDERS AND CREAM POWDER (CODEX STAN 207-1999), in: CODEX ALIMENTARIUS, 1999.

[40]P.K. Hla, S. Hogekamp, Wetting behaviour of instantized cocoa beverage powders, International Journal of Food Science \& Technology. 34 (1999) 335-342. https://doi.org/10.1046/j.1365-2621.1999.00275.x.

[41]C. Gaiani, J.J. Ehrhardt, J. Scher, J. Hardy, S. Desobry, S. Banon, Surface composition of dairy powders observed by X-ray photoelectron spectroscopy and effects on their rehydration properties, Colloids and Surfaces B: Biointerfaces. 49 (2006) 71-78. https://doi.org/10.1016/j.colsurfb.2006.02.015.

[42] A. Sharma, A.H. Jana, R.S. Chavan, Functionality of Milk Powders and Milk- Based Powders for End Use Applications - A Review, Comprehensive Reviews in Food Science and Food Safety. 11 (2012) 518-528. https://doi.org/10.1111/j.1541-4337.2012.00199.x.

[43]H. Singh, A. Ye, Controlling milk protein interactions to enhance the reconstitution properties of whole milk powders - A minireview, Dairy Sci. Technol. 90 (2010) 123-136. https://doi.org/10.1051/dst/2009038.

[44] A.K. Shrestha, T. Howes, B.P. Adhikari, B.J. Wood, B.R. Bhandari, Effect of protein concentration on the surface composition, water sorption and glass transition temperature of spray-dried skim milk powders, Food Chemistry. 104 (2007) 1436-1444. https://doi.org/10.1016/j.foodchem.2007.02.015.

[45]E.H.-J. Kim, Surface composition of industrial spray-dried dairy powders and its formation mechanisms, 2008.

[46] Q. Zhou, B. Armstrong, I. Larson, P.J. Stewart, D.A.V. Morton, Effect of host particle size on the modification of powder flow behaviours for lactose monohydrate following dry coating, Dairy Sci. Technol. 90 (2010) 237-251. https://doi.org/10.1051/dst/2009046.

[47]E. Gnagne, J. Petit, C. Gaiani, J. Scher, G. Amani, Characterisation of flow properties of foutou and foufou flours, staple foods in West Africa, using the FT4 powder rheometer, (2017).

[48]M. Deli, J. Petit, R.M. Nguimbou, E. Beaudelaire Djantou, N. Njintang Yanou, J. Scher, Effect of sieved fractionation on the physical, flow and hydration properties of Boscia senegalensis Lam., Dichostachys 


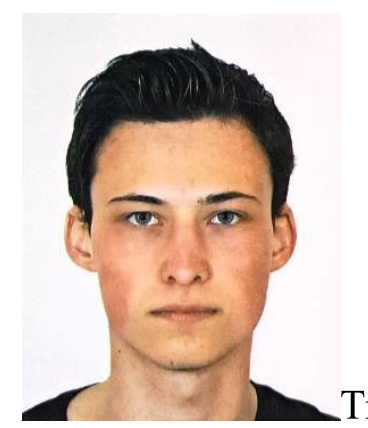

Tristan Fournaise graduated with Technology University degree in Food

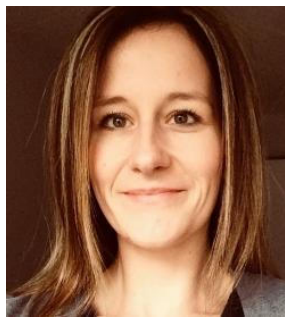

Dr Jennifer BURGAIN is assistant professor at the ENSAIA (French

engineering school in agricultural and food sciences, University of Lorraine, Nancy, France) since 2017. She obtained her PhD in 2013 working on the encapsulation of lactic acid bacteria and 616 bacterial adhesion to dairy matrices. She then performed two postdoctoral work industry in relation 617 to food powders both funded by food. She is still working on bacterial adhesion to food matrices, 618 stabilizing processes and also on rehydration properties of food powders. She teaches dairy 
came from an initial training in manipulations of biotechnology.

624 Following my arrival at the Laboratoire d'Ingénierie des Biomolécules in 2006 I have adapted 625 and trained myself in the production and analysis of physical and chemical characterization of food 626 powders. Since then I mobilize my technical skills to collaborate through various research projects 627 in this area.

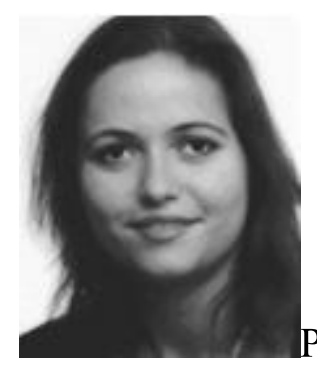

Prof Claire Gaiani Since my recruitment in 2007, I have received a total of $6302000 \mathrm{k} €$ in funding for projects on which I was the principal investigator. Among other important 631 activities, I successfully managed fundamental competitive programs including the French ANR 632 (French National Agency for Research) and European projects (Excellent science section with 633 a Marie Sklodowska-Curie action and Interreg). Finally, I manage many industrial partnerships with 634 leading international food companies (including Nestle, Lactalis, Bel, Bongrain, and Senoble). All 635 these projects are directly related to my research theme. 
Prof Joël Scher is a Professor in the ENSAIA (French engineering school

637 in agricultural and food sciences, University of Lorraine, Nancy, France) since 2006. He was the

638 director of the Biomolecules Engineering Laboratory (LIBio). His research focuses on Science and

639 Engineering of the Elaboration of Food Materials. He is the supervisor of two courses at the

640 ENSAIA who deal with dairy product and quality since 2000 and dairy industry since 2005.

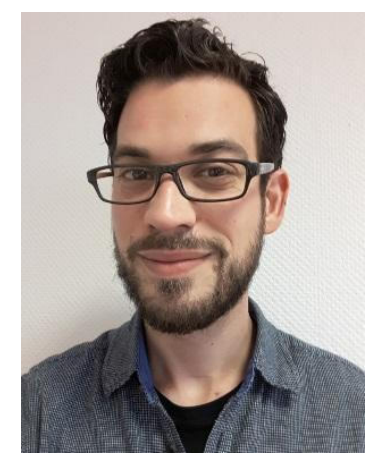
Since 2012, Jeremy PETIT holds a lecturer position at the ENSAIA (French

643 engineering school in agricultural and food sciences, University of Lorraine, Nancy, France).

644 Engineer graduated from the École Centrale Paris in 2005, he obtained in 2009 his PhD at the 645 Alternative Energies and Atomic Energy Commission working on hyphenated HPLC-ICPMS. 646 Then, he performed three postdoctoral fellowships at the French National Institute for Agricultural 647 Research working on heat exchanger fouling by dairy products.

648 He now teaches process engineering and physicochemistry. His research theme concerns the 649 impact of formulation and process conditions on physicochemistry and functionality of food 650 powders. 
Table 1. Proximate composition on dry basis of powders produced byconcentrates used to feed spray-drying, deduced from calculations on the basis of technical datasheet of commercial powders used to prepare feed concentrates employed in the preparation of concentrates.

\begin{tabular}{ccccc}
\hline Powders & Proteins (\%) & Lipids (\%) & Lactose (\%) & Minerals (\%) \\
\hline $\begin{array}{c}\text { Commercial skim milk powder/aerated } \\
\text { skim milk powder (SMP/ASMP) }\end{array}$ & $>32.9$ & $<1.5$ & $<56.0$ & $<8.5$ \\
$\begin{array}{c}\text { Semi-skim milk powder*taerated semi } \\
\text { skim milk powder (SSMP/ASSMP) }\end{array}$ & $>28.8$ & $>13.8$ & $<48.5$ & $<7.5$ \\
$\begin{array}{c}\text { Commercial whole milktaerated whole } \\
\text { milk powder (WMP/AWMP) powder }\end{array}$ & $>24.7$ & $>26.0$ & $<41.0$ & $<6.5$ \\
\hline
\end{tabular}

* Mix between $50 \%$ of commercial skim milk powder and $50 \%$ of whole milk powder

Table 2. Granulometer parameters $\left(\mathrm{d}_{10}, \mathrm{~d}_{50}, \mathrm{~d}_{90}\right.$, span) of SMP, SSMP, WMP, ASMP, ASSMP and AWMP.

\begin{tabular}{lcccc}
\hline Sample & $\mathrm{d}_{10}(\mu \mathrm{m})$ & $\mathrm{d}_{50}(\mu \mathrm{m})$ & $\mathrm{d}_{90}(\mu \mathrm{m})$ & Span $(-)$ \\
\hline SMP & $8.7^{\mathrm{b}} \pm 0.1$ & $36.7^{\mathrm{a}} \pm 0.2$ & $137.0^{\mathrm{a}} \pm 0.0$ & $3.5^{\mathrm{a}} \pm 0.0$ \\
SSMP & $9.2^{\mathrm{a}} \pm 0.0$ & $29.6^{\mathrm{b}} \pm 0.1$ & $94.3^{\mathrm{b}} \pm 0.4$ & $2.9^{\mathrm{c}} \pm 0.0$ \\
WMP & $9.1^{\mathrm{a}} \pm 0.1$ & $27.7^{\mathrm{c}} \pm 0.2$ & $92.2^{\mathrm{b}} \pm 2.0$ & $3.0^{\mathrm{b}} \pm 0.1$ \\
\hline ASMP & $7.4^{\mathrm{c}} \pm 0.1$ & $21.0^{\mathrm{d}} \pm 0.1$ & $49.8^{\mathrm{d}} \pm 0.1$ & $2.0^{\mathrm{f}} \pm 0.0$ \\
ASSMP & $5.9^{\mathrm{d}} \pm 0.0$ & $19.3^{\mathrm{e}} \pm 0.1$ & $47.3^{\mathrm{e}} \pm 0.2$ & $2.1^{\mathrm{e}} \pm 0.0$ \\
AWMP & $6.1^{\mathrm{d}} \pm 0.1$ & $20.8^{\mathrm{d}} \pm 0.0$ & $58.8^{\mathrm{c}} \pm 0.1$ & $2.5^{\mathrm{d}} \pm 0.0$
\end{tabular}

Means with different superscripted letters in the same column were significantly different according to Tukey's HSD test $(\mathrm{p}<0.05 ; \mathrm{n}=3)$. 
Table 3. Techno-functional characterization (reconstitution) of SMP, SSMP, WMP, ASMP, ASSMP and AWMP.

\begin{tabular}{cccccc}
\hline Sample & $\begin{array}{c}\text { Water content } \\
(\mathrm{g} / 100 \mathrm{~g})\end{array}$ & $\begin{array}{c}\text { Water activity } \\
\mathrm{a}_{\mathrm{w}}(-)\end{array}$ & $\begin{array}{c}\text { Wettability } \\
(\mathrm{min})\end{array}$ & $\begin{array}{c}\text { Dispersibility } \\
(\%)\end{array}$ & $\begin{array}{c}\text { Solubility } \\
(\%)\end{array}$ \\
\hline SMP & $4.98^{\mathrm{a}} \pm 0.05$ & $0.25^{\mathrm{c}} \pm 0.00$ & $>90<90$ & $23.81^{\mathrm{a}} \pm 0.09$ & $93.28^{\mathrm{a}} \pm 5.27$ \\
SSMP & $3.14^{\mathrm{c}} \pm 0.02$ & $0.21^{\mathrm{d}} \pm 0.00$ & $>90<90$ & $14.89^{\mathrm{d}} \pm 0.45$ & $93.83^{\mathrm{a}} \pm 2.10$ \\
WMP & $2.04^{\mathrm{d}} \pm 0.07$ & $0.15^{\mathrm{f}} \pm 0.00$ & $>90<90$ & $19.79^{\mathrm{b}} \pm 0.08$ & $92.65^{\mathrm{a}} \pm 4.20$ \\
\hline ASMP & $3.78^{\mathrm{b}} \pm 0.09$ & $0.18^{\mathrm{e}} \pm 0.00$ & $>90<90$ & $20.03^{\mathrm{b}} \pm 0.28$ & $91.97^{\mathrm{a}} \pm 3.20$ \\
ASSMP & $3.64^{\mathrm{b}} \pm 0.13$ & $0.28^{\mathrm{b}} \pm 0.00$ & $>90<90$ & $12.65^{\mathrm{e}} \pm 0.06$ & $88.96^{\mathrm{a}} \pm 1.71$ \\
AWMP & $3.82^{\mathrm{b}} \pm 0.17$ & $0.29^{\mathrm{a}} \pm 0.00$ & $>90<90$ & $15.94^{\mathrm{c}} \pm 0.22$ & $93.33^{\mathrm{a}} \pm 2.75$ \\
\hline
\end{tabular}

Means with different superscripted letters in the same column were significantly different according to Tukey's HSD test $(\mathrm{p}<0.05 ; \mathrm{n}=3)$. 
Table 4. Flowability characterization (Stability test, compressibility test, shear cell test) of SMP, SSMP, WMP, ASMP, ASSMP and AWMP.

\begin{tabular}{|c|c|c|c|c|c|c|c|}
\hline Sample & $\mathrm{BFE}(\mathrm{mJ})$ & $\mathrm{SE}(\mathrm{mJ} / \mathrm{g})$ & $\mathrm{CBD}(\mathrm{g} / \mathrm{mL})$ & $\mathrm{BD}(\mathrm{g} / \mathrm{mL})$ & $\begin{array}{l}\text { Compressibility } \\
\text { at } 15 \mathrm{kPa}(\%)\end{array}$ & $\begin{array}{l}\text { Cohesion } \\
(\mathrm{kPa})\end{array}$ & $f f(-)$ \\
\hline SMP & $48.74^{c} \pm 5.55$ & $5.27^{\mathrm{d}} \pm 0.37$ & $0.52^{\mathrm{a}} \pm 0.01$ & $\begin{array}{l}0.62^{\mathrm{b}} \pm 0.01 \\
0.62^{\mathrm{ab}} \pm 0.02\end{array}$ & $16.13^{\mathrm{c}} \pm 0.91$ & $0.77^{\mathrm{b}} \pm 0.06$ & $5.59^{\mathrm{b}} \pm 0.36$ \\
\hline SSMP & $72.63^{b} \pm 7.53$ & $7.03^{c} \pm 0.08$ & $0.38^{\mathrm{b}} \pm 0.02$ & $\begin{array}{l}0.67^{\mathrm{ab}} \pm 0.00 \\
0.51^{\mathrm{b}} \pm 0.02\end{array}$ & $42.50^{\mathrm{ab}} \pm 3.54$ & $2.07^{\mathrm{a}} \pm 0.07$ & $2.30^{\mathrm{c}} \pm 0.07$ \\
\hline WMP & $91.97^{b} \pm 2.71$ & $7.80^{\mathrm{c}} \pm 0.58$ & $0.39^{\mathrm{b}} \pm 0.01$ & $\begin{array}{l}0.65^{\mathrm{ab}} \pm 0.05 \\
0.74^{\mathrm{a}} \pm 0.12\end{array}$ & $39.44^{\mathrm{b}} \pm 3.67$ & $2.20^{\mathrm{a}} \pm 0.39$ & $2.28^{\mathrm{c}} \pm 0.34$ \\
\hline ASMP & $76.33^{b} \pm 7.63$ & $7.67^{\mathrm{c}} \pm 0.63$ & $0.55^{\mathrm{a}} \pm 0.03$ & $\begin{array}{l}0.66^{\mathrm{ab}} \pm 0.03 \\
0.62^{\mathrm{ab}} \pm 0.01\end{array}$ & $14.37^{\mathrm{c}} \pm 3.13$ & $0.59^{b} \pm 0.13$ & $7.41^{\mathrm{a}} \pm 1.41$ \\
\hline ASSMP & $135.64^{\mathrm{a}} \pm 14.02$ & $9.94^{\mathrm{b}} \pm 0.35$ & $0.37^{\mathrm{b}} \pm 0.02$ & $\begin{array}{l}0.63^{\mathrm{b}} \pm 0.02 \\
0.63^{\mathrm{ab}} \pm 0.03\end{array}$ & $42.20^{\mathrm{ab}} \pm 1.64$ & $2.41^{\mathrm{a}} \pm 0.14$ & $2.01^{\mathrm{c}} \pm 0.07$ \\
\hline AWMP & $156.15^{\mathrm{a}} \pm 8.44$ & $11.68^{\mathrm{a}} \pm 0.06$ & $0.36^{\mathrm{b}} \pm 0.01$ & $\begin{array}{l}0.70^{\mathrm{a}} \pm 0.02 \\
0.70^{\mathrm{ab}} \pm 0.17\end{array}$ & $48.79^{\mathrm{a}} \pm 1.47$ & $2.59^{\mathrm{a}} \pm 0.29$ & $1.86^{\mathrm{c}} \pm 0.13$ \\
\hline
\end{tabular}

Means with different superscripted letters in the same column were significantly different according to Tukey's HSD test $(\mathrm{p}<0.05 ; \mathrm{n}=3)$. 


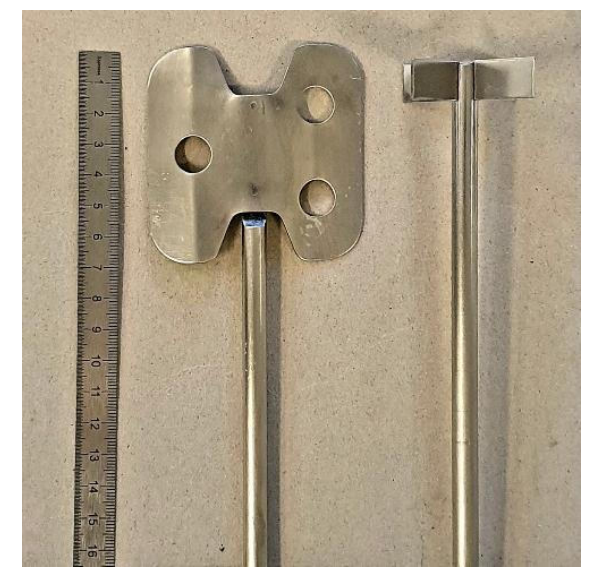

Fig. 1. 3-hole square and 4-bladed impellers.

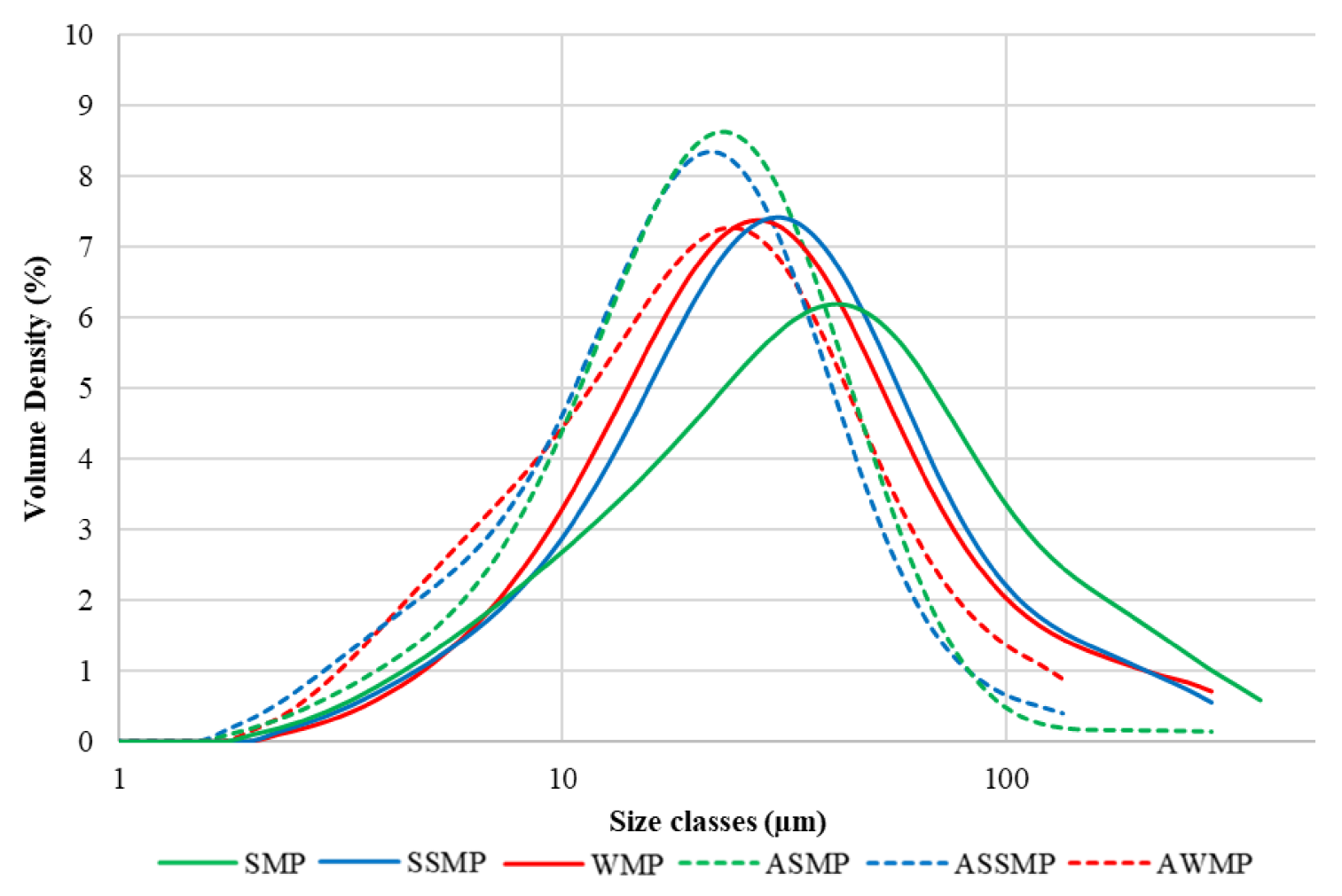

Fig. 2. Particle size distributions (in volume) of SMP, SSMP, WMP ASMP, ASSMP and AWMP. 


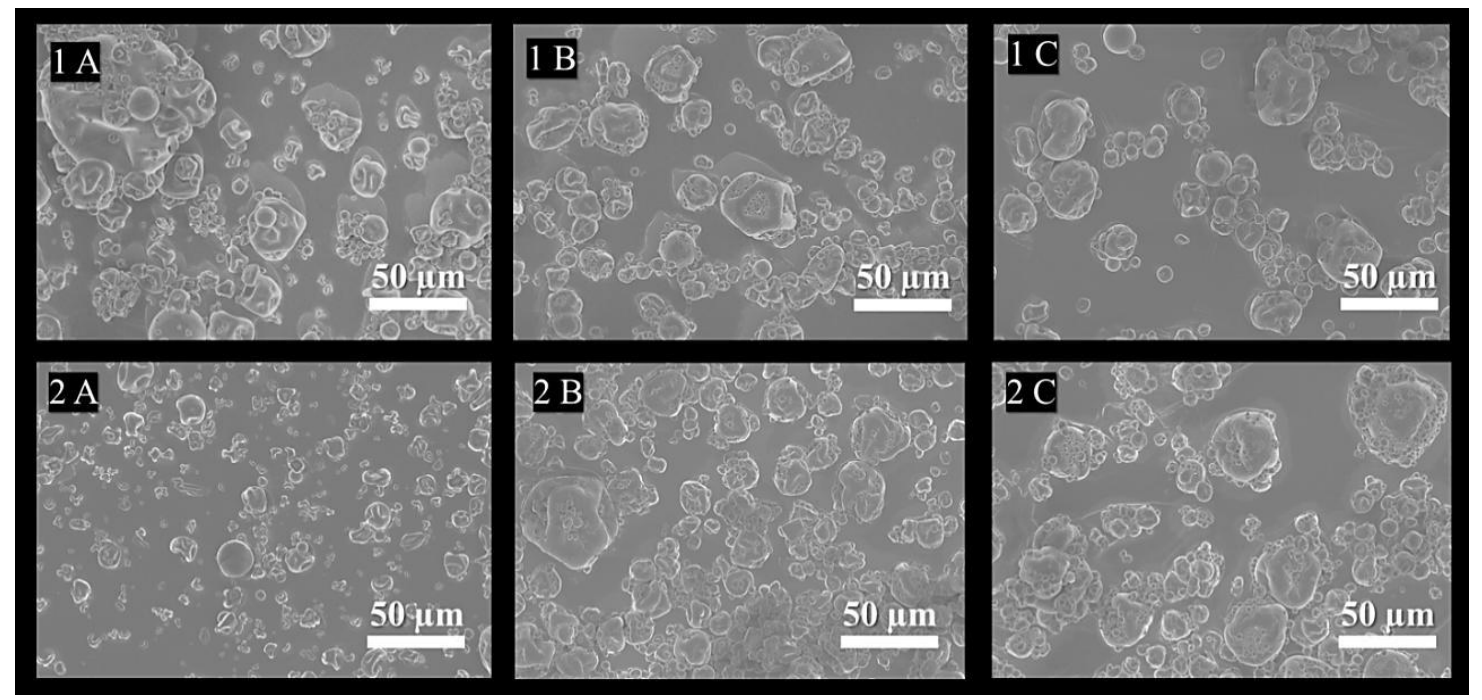

Fig. 3. SEM micrographs of spray-dried milk powders varying in lipid content (1 A: SMP; 2 A: ASMP; 1 B: SSMP; 2 B ASSMP; 1 C: WMP; 2 C: AWMP). Magnification: $\times 500$.

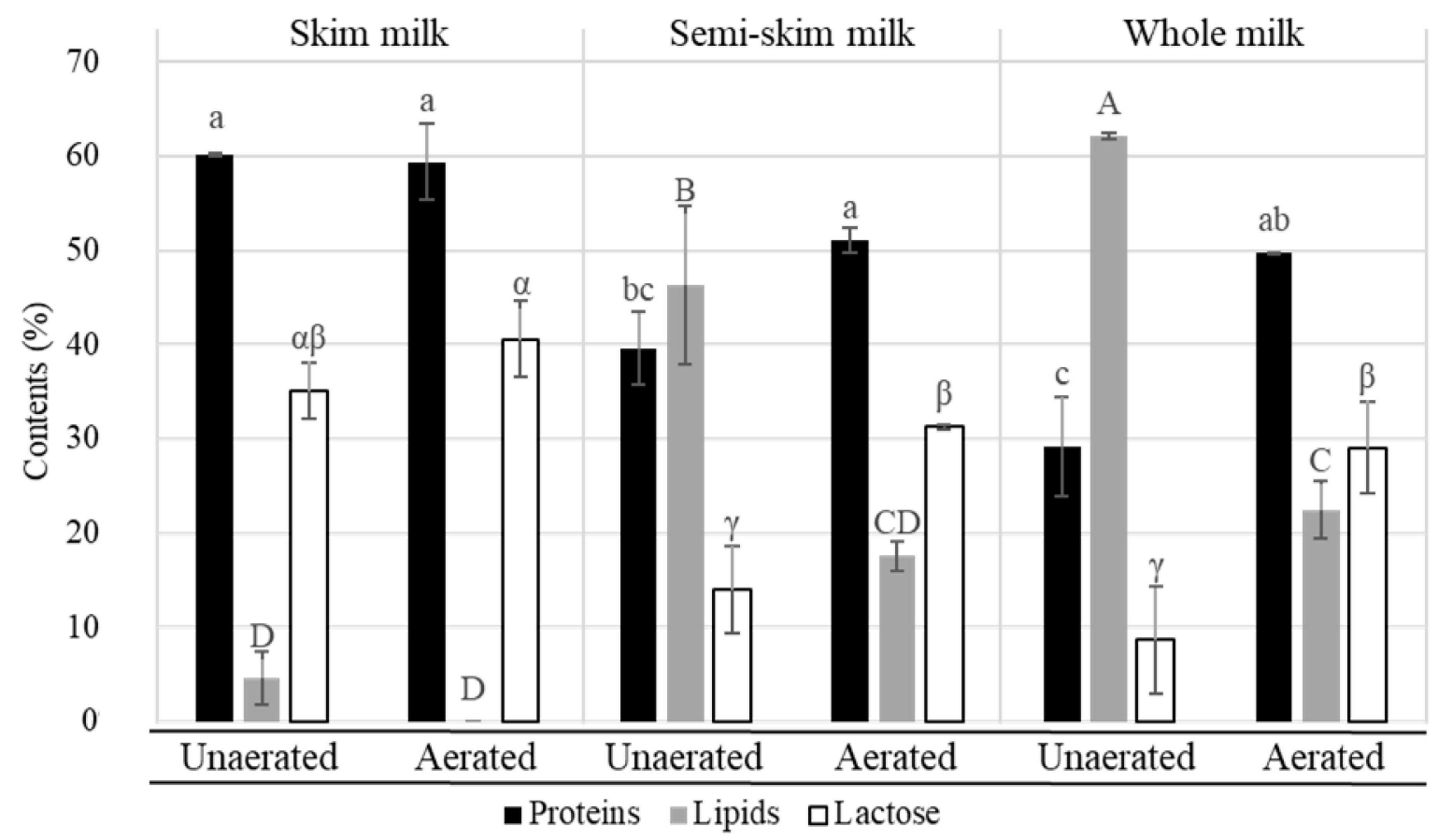

Fig. 3. Surface composition on dry basis deduced from XPS analysis of skim, semi-skim and whole milk powders with or without aeration. For each component separately, bars topped with different letters were significantly different according to Tukey's HSD test $(\mathrm{p}<0.05 ; \mathrm{n}=2)$. 


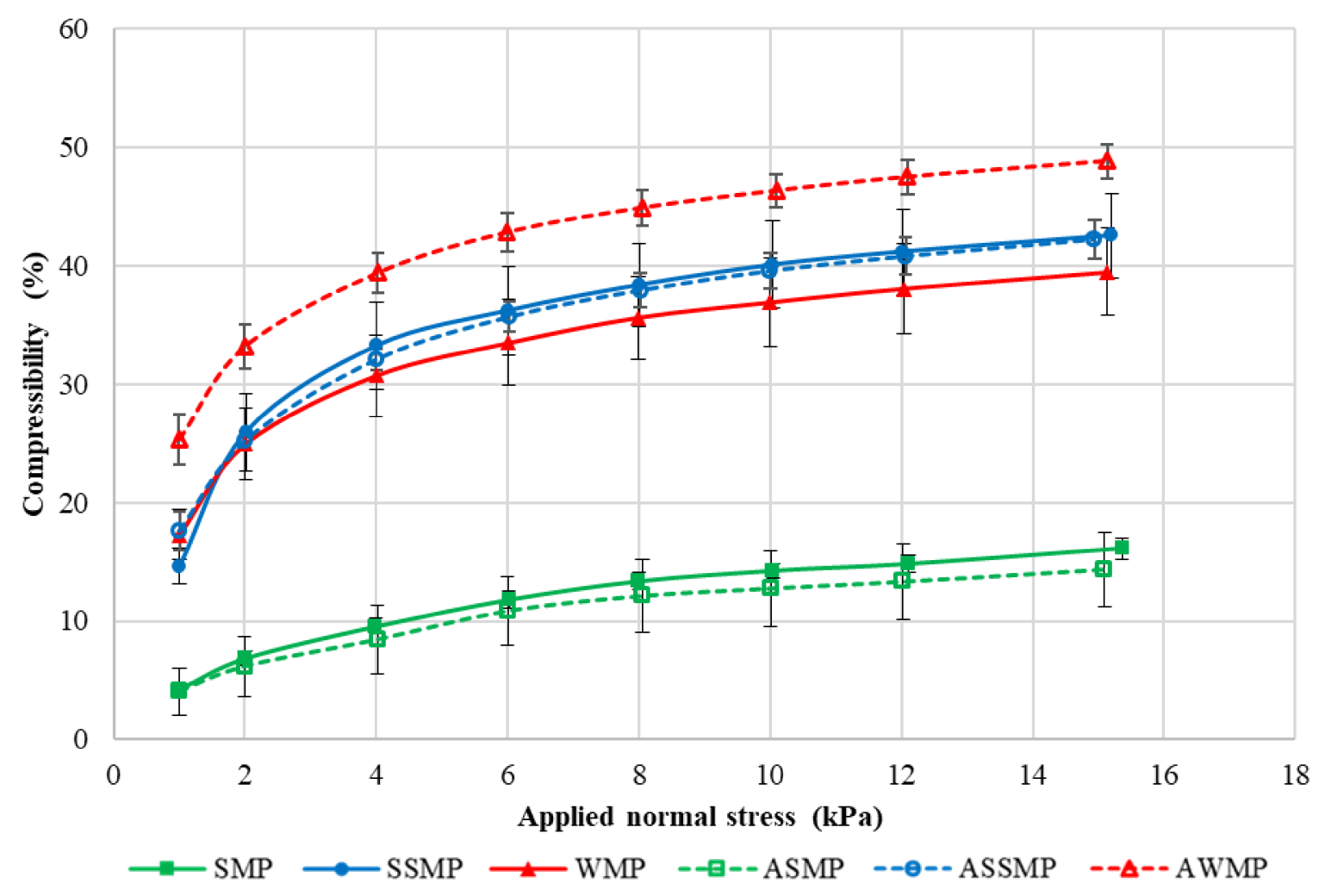

Fig. 4. Compressibility results for SMP, SSMP, WMP, ASMP, ASSMP and AWMP.



Fig. 5. Shear test results for SMP, SSMP, WMP, ASMP, ASSMP and AWMP. 